\title{
Homer/VesI Proteins and Their Roles in CNS Neurons
}

\section{Markus U. Ehrengruber, ${ }^{*}, 1,2$ Akihiko Kato, ${ }^{3}$ Kaoru Inokuchi, ${ }^{4}$ and Sonia Hennou ${ }^{2}$}

\author{
${ }^{1}$ Kantonsschule Hohe Promenade, Promenadengasse 11, CH-8001 Zurich, Switzerland; \\ ${ }^{2}$ Brain Research Institute, University of Zurich, CH-8057 Zurich, Switzerland; \\ ${ }^{3}$ Department of Physiology, University of California, San Francisco, CA, 94107; \\ ${ }^{4}$ Mitsubishi Kagaku Institute of Life Sciences (MITILS), Tokyo 194-8511, Japan
}

\begin{abstract}
Since their initial discovery in 1997, Homer/Vesl proteins have become increasingly investigated as putative regulators of receptor and ion-channel function in the central nervous system. Within a relatively brief period, numerous research reports have described manifold effects of Homer proteins, including the modulation of the trafficking of type I metabotropic glutamate receptors (mGluRs), axonal pathfinding, mGluR coupling to calcium and potassium channels, agonist-independent mGluR activity, ryanodine receptor regulation, locomotor activity, and behavioral plasticity. This review summarizes our current knowledge on the induction, expression, and structure of the various forms of Homer proteins, as well as their roles in neuronal function. In addition, we provide an outlook on novel developments with regard to the involvement of Homer-1a in hippocampal synaptic function.
\end{abstract}

Index Entries: hippocampus; immediate early gene; inositol (1,4,5)-trisphosphate receptor; metabotropic glutamate receptor; ryanodine receptor; Shank protein; synaptic transmission.

\section{Introduction}

Homer/Vesl (ASP/Ena-related protein induced during seizure and LTP) proteins localize to the molecular scaffold at postsynaptic den-

Received 6/25/03; Accepted 10/23/03

* Author to whom all correspondence and reprint requests should be addressed. E-mail: markus.ehrengruber@ hopro.ch sities of excitatory synapses in the mammalian brain (1-4). Postsynaptic targeting of Homer proteins presumably occurs via their binding to proline-rich sequences that are present in type I metabotropic glutamate receptors (mGluRs), inositol $(1,4,5)$-trisphosphate receptors $\left(\mathrm{IP}_{3} \mathrm{Rs}\right)$, ryanodine receptors (RyRs) type 1 and 2, C-type transient receptor potential (TRPC) channels, Shank proteins, and dynamin 3 (see below). It is therefore possible that Homer proteins regulate the number of neurotransmitter receptors in the 


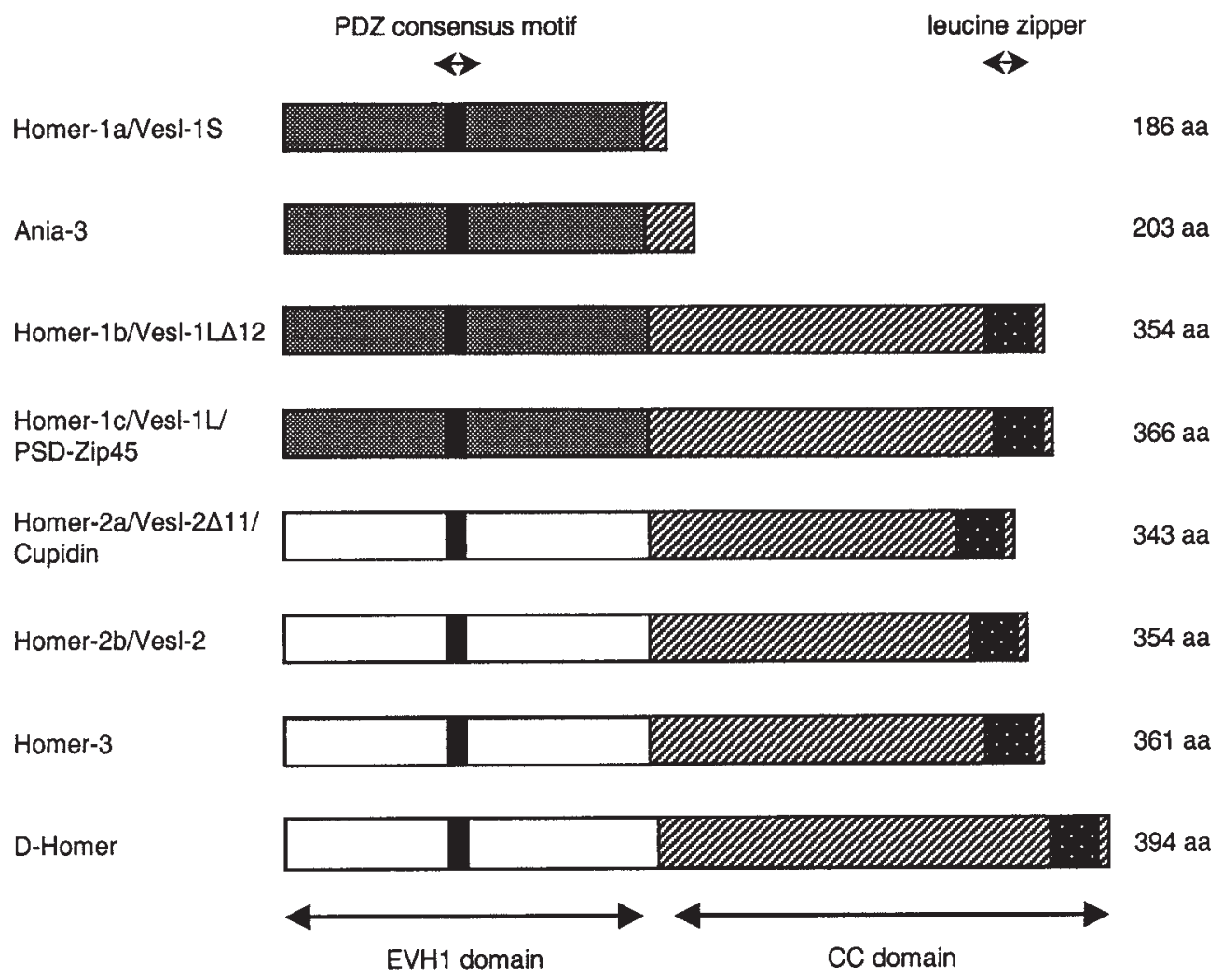

Fig. 1. Schematic representation of the Homer protein family members. Based on their number of amino acid residues, Homer proteins can be grouped into short (around $200 \mathrm{aa}$ ) and long (>300 aa) forms. All Homer proteins contain an EVH1-like domain, including a single PDZ consensus motif (black), in the N-terminal via which type I mGluRs (mGluR1a/5) are bound. Except for the two short forms Homer-1a and Ania-3, all Homer proteins possess at their C-terminus a predicted coiled-coil (CC) domain that includes several leucine zipper motifs.

postsynaptic membrane and/or their functional coupling to intracellular signal transduction cascades, thereby modulating synaptic strength. In this review, we first characterize the Homer proteins as well as their interactions with known binding partners, then summarize the published data on functional effects of Homer proteins, and finally discuss the putative involvement of Homer proteins in hippocampal synaptic transmission.

\section{The Homer Family}

Several Homer family members have been identified in mammals, amphibians, and insects.
A total of 12 Homer cDNAs have been cloned from rat, mouse (5,6), Drosophila (7), and human brains (6). Proteins encoded by these cDNAs share a similar structure and are splice variants of three independent mammalian genes (homer-1, 2, and 3) and of one Drosophila gene (D-homer).

Alternative splicing of the homer- 1 gene leads to four isoforms, i.e., Homer-1a/Vesl-1S, Ania$3 /$ Vesl-1M, Homer-1b/Vesl-1 $\Delta 12$, and Homer1c/Vesl-1L/PSD-Zip45 (Fig. 1). Based on their number of amino acid residues, Homer proteins can be grouped into short (around 200 aa) and long (>300 aa) forms, e.g., Homer-1a and Ania-3 vs. Homer-1b/c. The first discovered member of the family was Homer-1a, identified 
Table 1

Stimuli That Induce Homer-1a mRNA

\begin{tabular}{|c|c|c|}
\hline Tissue & Treatment & Refs. \\
\hline Hippocampus & $\begin{array}{l}\text { kainate injection } \\
\text { tetanic stimuli } \\
\text { synaptogenesis } \\
\text { electroconvulsive seizure } \\
\text { epileptic seizure }\end{array}$ & $8,9,11,56$ \\
\hline Striatum & quinpirole & 10 \\
\hline $\begin{array}{l}\text { Hypothalamic suprachiasmatic } \\
\text { nucleus }\end{array}$ & $\begin{array}{l}\text { light } \\
\text { pituitary adenylate cyclase activating polypeptide } \\
\text { glutamate }\end{array}$ & 57,58 \\
\hline Hypothalamus, neocortex & exploration of a novel environment & 59 \\
\hline $\begin{array}{l}\text { Caudate putamen, nucleus } \\
\text { accumbens }\end{array}$ & $\begin{array}{l}\text { haloperidol } \\
\text { clozapine } \\
\text { olanzapine }\end{array}$ & 60,61 \\
\hline $\begin{array}{l}\text { Cultured hippocampal and cortical } \\
\text { neurons }\end{array}$ & $\begin{array}{l}\text { phorbol esters } \\
\text { proteasome inhibitors }\end{array}$ & $2,62,63$ \\
\hline Cultured cerebellar granule cells & $\begin{array}{l}\text { TEA + 4-AP } \\
\text { NMDA } \\
\text { kainate } \\
\text { BDNF } \\
\text { glutamate }\end{array}$ & 29,64 \\
\hline
\end{tabular}

Expression of Homer-1a, the short splice isoform of the homer-1 gene, is induced by numerous stimuli in several areas of the brain including the hippocampus, the hypothalamus, the striatum, the nucleus accumbens, the neocortex, and the cerebellum. Upregulation of Homer-1a expression was found both in vitro and in vivo (adapted from ref. 65).

as an immediate-early gene (IEG) in neurons from seizure-stimulated rat hippocampus $(8,9)$. In situ hybridization showed that Homer-1a is a neuron-specific splice isoform that is rapidly and transiently upregulated by synaptic activity (8). Table 1 summarizes the known stimuli that cause neuronal Homer-1a expression both in vitro and in vivo. Similar to Homer-1a, Ania3 is an activity-dependent and neuron-specific form, induced by dopamine-dependent signals and seizures in rodent striatum, forebrain, and dentate gyrus of the hippocampus $(10,11)$. Both Homer-1a and Ania-3 are upregulated within minutes upon neuronal stimulation $(8,9,11)$. In contrast to Homer-1a and Ania-3, Homer- $1 \mathrm{~b}$ and Homer-1c are constitutively expressed splice isoforms without any activity-dependent regulation; they occur in both neuronal and non-neuronal cells $(5,6,11,12)$. Two splice isoforms of the homer-2 gene have been described so far $(1,5,6)$. Homer-2a/Vesl-2 $\Delta 11 /$ cupidin and Homer-2b/Vesl-2 were cloned based on their sequence similarity with Homer-1a $(5,6)$ and exhibit a developmental increase in postnatal day 7 mouse cerebellum (1). Similar to Homer-1b/c, Homer-2a and Homer-2b are constitutively expressed in both neurons and other cells, and no modulation of their expression levels in mature neurons has been reported.

For the homer-3 gene, only one product has been described (6). Again, it was cloned on the basis of sequence similarity with Homer-1a, and no activity-dependent modulation of its expression levels was found.

The mammalian brain constitutively expresses high mRNA levels for Homer-1b/c, 
2, and 3 (13). For example, long forms of Homer proteins are found in the postsynaptic elements of cerebellar granule cells, hippocampal neurons, and retinal ganglion cells $(1-4,14)$. High levels of these mRNAs and proteins also occur in mouse heart and skeletal muscle, and in the diaphragm $(13,15)$.

\section{Homer Protein Structure}

Homer proteins belong to a wider family of PDZ domain-containing proteins $(16,17)$. The $\mathrm{N}$-terminal 110 amino acid residues of Homer proteins share sequence and secondary structure similarity with (a) the Ena/VASP homology domain 1 (EVH1 domain) of the Enabled protein of Drosophila (Ena) (18), (b) the vasodilator-stimulated phosphoprotein (VASP) $(19,20)$, and (c) the Ran-binding protein family (21). All these proteins have been implicated in binding to proline-rich domains of various cytoskeletal proteins. Although the EVH1 domains of the different Homer family members share $70-90 \%$ sequence identity, they are not more than 35\% identical to the EVH1 domains found in other proteins such as Ena or VASP. Crystal structure analyses as well as interaction studies showed that the peptide motif PPxxF that is bound by Homer-type EVH1 domains differs from the proline-rich motifs interacting with other EVH1 domains $(22,23)$. So far, several partners have been described that bind Homer proteins, including type I mGluRs, $\mathrm{IP}_{3} \mathrm{Rs}$, RyRs, TRPC channels, Shank/ProSAP scaffolding proteins, and dynamin 3 (see below).

Except for Homer-1a and Ania-3, the two short isoforms of the homer-1 gene, all long Homer isoforms contain a C-terminal domain with a predicted coiled-coil (CC) structure (Fig. $1)$. The Homer CC domain is necessary for the formation of Homer dimers and tetramers $(5,6)$. Furthermore, it includes one or two typical leucine zipper motifs that support further multimerization of at least some isoforms $(1,5,24)$. Homer-1c diverges from Homer- $1 \mathrm{~b}$ by a 12-amino acid residue insertion between the $\mathrm{N}$-terminus and the CC domain (6).
The N-terminal 110 amino acid residues of Drosophila Homer, which contain the EVH1 domain, are $73 \%$ identical with rodent Homer1 proteins, while the C-terminal region exhibits only $25 \%$ identity with Homer- $1 \mathrm{~b}$. Nevertheless, the fly Homer protein, compared to vertebrate Homer forms, shares common amino acid residues within the $C C$ domain and the two putative leucine zippers, allowing the multimerization of Drosophila Homer proteins.

\section{Homer Protein-Binding Partners}

\section{Type I Metabotropic Glutamate Receptors (mGluRs)}

Yeast two-hybrid and coimmunoprecipitation assays revealed that all Homer proteins bind to the cytoplasmic tails of mGluR1a and mGluR5 (termed group or type I mGluRs) both in vitro and in vivo $(1,5,6,8,12)$. Deletion analysis has identified a proline-rich Homer ligand consensus sequence (PPxxF) approx 50 amino acid residues from the $\mathrm{C}$-terminus of type I mGluRs that is crucial for Homer binding (23). This finding provides an interesting clue to the function of Homer proteins as type I mGluRs couple to phospholipase $\mathrm{C}$ and activate hydrolysis of phosphoinositides, thereby generating inositol trisphosphate $\left(\mathrm{IP}_{3}\right)$ and diacylglycerol.

Several ectopic expression studies have provided evidence for an alteration in the cellular distribution of mGluRs induced by Homer proteins, as listed in Table 2. Depending on the cell line used (HeLa, HEK 293, COS-7, and Ptk2 cells), various results have been obtained. In summary, diffuse plasma membrane localization of mGluR1a/5 occurred when the receptor was expressed alone. Cotransfection of Homer-1a had no effect on the distribution of mGluR1a/5 (24-26, see also 27), while coexpression of Homer-1b/c either clustered the receptor at the plasma membrane $(24,28)$ or decreased its surface expression by retarding mGluR1a/5 in the endoplasmatic reticulum $(25,28$, see also 26$)$. The effect of Homer-1b on 
Table 2

Effect of Homer-1 Proteins on Type I mGluR Trafficking in Cotransfection Systems

\begin{tabular}{|c|c|c|c|c|c|c|c|}
\hline \multirow[b]{2}{*}{ Cell type } & \multicolumn{2}{|c|}{ Homer-1a } & \multicolumn{2}{|c|}{ Homer-1b } & \multicolumn{2}{|c|}{ Homer-1c } & \multirow[b]{2}{*}{ Refs. } \\
\hline & mGluR1a & mGluR5 & mGluR1a & mGluR5 & mGluR1a & mGluR5 & \\
\hline HeLa & no effect & no effect & $\begin{array}{l}\text { retention } \\
\text { in ER }\end{array}$ & $\begin{array}{l}\text { retention } \\
\text { in ER }\end{array}$ & n.d. & n.d. & 25 \\
\hline \multirow[t]{2}{*}{ HEK 293} & $\begin{array}{l}\text { clustering } \\
\text { at PM }\end{array}$ & n.d. & n.d. & n.d. & $\begin{array}{l}\text { clustering } \\
\text { at PM }\end{array}$ & $\begin{array}{l}\text { decrease } \\
\text { at PM }\end{array}$ & 27,28 \\
\hline & no effect & n.d. & n.d. & n.d. & no effect & n.d. & 26 \\
\hline COS-7 & no effect & no effect & n.d. & n.d. & clustering & clustering & 24 \\
\hline Ptk2 & n.d. & n.d. & n.d. & n.d. & n.d. & $\begin{array}{l}\text { clustering } \\
\text { at PM }\end{array}$ & 48 \\
\hline \multirow[t]{2}{*}{$\begin{array}{l}\text { Cerebellar } \\
\text { granule cells }\end{array}$} & n.d. & $\begin{array}{l}\text { targeting } \\
\text { to dendrites } \\
\text { and axons }\end{array}$ & n.d. & $\begin{array}{l}\text { targeting } \\
\text { to dendrites }\end{array}$ & n.d. & $\begin{array}{l}\text { targeting to } \\
\text { dendrites }\end{array}$ & 29 \\
\hline & n.d. & $\begin{array}{l}\text { PM surface } \\
\text { expression }\end{array}$ & nd. & $\begin{array}{l}\text { intracellular } \\
\text { retention }\end{array}$ & n.d. & n.d. & 33 \\
\hline $\begin{array}{l}\text { Cortical } \\
\text { neurons }\end{array}$ & n.d. & n.d. & n.d. & n.d. & $\begin{array}{l}\text { targeting } \\
\text { to dendrites }\end{array}$ & n.d. & 28 \\
\hline $\begin{array}{l}\text { Hippocampal } \\
\text { neurons }\end{array}$ & n.d. & n.d. & n.d. & n.d. & n.d. & $\begin{array}{l}\text { clustering } \\
\text { at PM }\end{array}$ & 48 \\
\hline
\end{tabular}

The table summarizes the varying results obtained with the coexpression of Homer-1 proteins and type I mGluRs in cell lines and cultures of dissociated neurons. Abbreviations: ER, endoplasmic reticulum; n.d., not determined; PM, plasma membrane.

mGluR5 trafficking was abolished by point mutations in the Homer binding site of mGluR5 (i.e., PPSPF), which demonstrates that Homer- $1 \mathrm{~b}$ affects mGluR5 localization via a direct protein-protein interaction (25).

Similar to cell lines, mGluR5 also localizes to the cell bodies of cerebellar granule cells when transfected alone (29). However, when coexpressed with Homer- $1 \mathrm{~b} / \mathrm{c}$, mGluR5 redistributed to dendrites (colocalizing with the presynaptic marker synaptophysin), whereas it was detected in both dendrites and axons when cotransfected with Homer-1a. Upregulation of endogenous Homer-1a (through depolarizing the neurons with a combination of ionotropic glutamate receptor agonists or with potassiumchannel blockers) also redistributes mGluR5 into neurites (29). In support of these data, another study found Homer-1c to increase the transport of mGluR1a into dendrites from cultured cortical neurons (28). Taken together, these results suggest that Homer proteins play an important role in the trafficking and targeting of type I mGluRs into dendrites and/or axons via a so-far-unknown mechanism.

\section{Inositol (1,4,5)-Trisphosphate Receptors (IP $R$ Rs)}

In hippocampal neurons, $\mathrm{IP}_{3} \mathrm{Rs}$ are restricted to dendritic shafts (30), whereas in cerebellar Purkinje cells they occur in spines, associating with the spine apparatus (31). Homer-1, 2, and 3 , by contrast, are enriched in the cytosol at the lateral margin of the postsynaptic density (PSD) (6). 
In cerebellar Purkinje cells, where $\mathrm{IP}_{3} \mathrm{Rs}$ and Homer proteins are highly enriched, an $\mathrm{IP}_{3} \mathrm{R}$ antibody specifically coimmunoprecipitates the long Homer forms (Homer-1b/c, 2a/b, and 3) and mGluR1a (22). As $\mathrm{IP}_{3}$ Rs are not known to directly bind to mGluR1a, it has been concluded that Homer proteins bridge $\mathrm{IP}_{3}$ Rs and mGluRs. This interaction is particularly important because $\mathrm{IP}_{3}$ Rs are downstream effectors of type I mGluRs and act as calcium-release channels in the endoplasmic reticulum (32). The connection between mGluRs and $\mathrm{IP}_{3} \mathrm{Rs}$, via Homer proteins, involves close proximity of both receptors, which may be a key feature of the postsynaptic mGluR-dependent signal transduction. A study of mGluR-induced calcium transients in Purkinje cells from primary cerebellar cultures showed that overexpression of Homer-1a, as compared to transfection with Homer- $1 \mathrm{~b}$, decreased the amplitude and increased the latency of mGluR-evoked $\mathrm{Ca}^{2+}$ responses (6). However, although the decay phase of the $\mathrm{Ca}^{2+}$ response was slower in neurons transfected with Homer1a, the total $\mathrm{Ca}^{2+}$ flux was similar to the one in cells overexpressing Homer-1b. Another study in cerebellar granule cells yielded conflicting results (33) in that cotransfection of mGluR5 with Homer-1a increased both the amplitude and latency of agonist-induced responses. The apparent contradiction may result from the different techniques used to detect intracellular $\mathrm{Ca}^{2+}$. While the former study analyzed the free intracellular $\mathrm{Ca}^{2+}$ concentration with fura-2 imaging, the latter one measured in a more indirect manner the activity of BK-type $\mathrm{K}^{+}$channels, which are activated by cytosolic $\mathrm{Ca}^{2+}$ increases. In addition, the first report, using quisqualate as an agonist, stimulated endogenous mGluR1/5 in Purkinje cells, while the second study, applying DHPG, activated ectopically expressed mGluR5 in cerebellar granule cells. In the latter case, the effect of Homer-1a was abolished by cotransfection with Homer-1b (33).

\section{Shank/ProSAP Proteins}

It has been shown with immunogold electron microscopic analysis that Shank, an NMDA receptor scaffolding protein, and Homer proteins colocalize at the PSD (34). In addition, when Homer-1b and Shank-1 were coexpressed in COS-7 cells and cell extracts immunoprecipitated with Shank antibodies, Homer-1b protein could be detected in the precipitates (34). The Homer-Shank interaction was confirmed in vivo by coimmunoprecipitation experiments using rat brain samples. As opposed to Homer proteins, the AMPA receptor scaffolding protein GRIP did not coprecipitate with anti-Shank antibodies, which confirms the specificity of the Homer-Shank interaction.

Experiments in cell cultures revealed that Homer- $1 \mathrm{a} / \mathrm{b} / \mathrm{c}$ proteins also interact with other components of the NMDA receptor/ PSD-95 complex (34). Homer-1b and PSD-95 coclustered only upon coexpression of Shank and guanylate kinase-associated protein (GKAP). These results indicate that Shank and GKAP participate in the formation of a quaternary protein complex including Shank, GKAP, PSD-95, and Homer proteins. In support of this suggestion, coexpression of Homer, Shank-1, and mGluR5 resulted in prominent coclustering of mGluR5 with Shank-1 in COS-7 cells, while cotransfection of Shank-1 with mGluR5 alone did not cluster the receptor. Also, the colocalization of mGluR5 and Shank-1 depended on the ability of Homer proteins to bind the receptor, because it was abolished by a point mutation in the Homer binding site of mGluR5. In summary, both Homer and Shank proteins are required to cluster mGluR5. By physically linking components of the NMDA and mGluR signaling pathways, the HomerShank interaction may contribute to glutamate-receptor cross-talk.

\section{Ryanodine Receptor Type 1 (RyR1)}

Homer expression has also been detected in skeletal and cardiac muscle $(13,15)$. Crystallographic analysis of the EVH1 domain of Homer- 1 revealed its specific association with the putative Homer binding sequence present in RyR1 (23). The physical interaction between RyR1 and Homer-1c/2/3 proteins was con- 
firmed by coimmunoprecipitation experiments using junctional membrane vesicles from the sarcoplasmic reticulum of skeletal muscle. Moreover, by analyzing macroscopic $\mathrm{Ca}^{2+}$ efflux and ryanodine binding, it was revealed that the interaction of Homer-1c with RyR1 significantly increased the $\mathrm{Ca}^{2+}$ responsiveness of RyR1 at the single-channel level, whereas mutating the Homer-ligand sequence of RyR1 reduced excitation-contraction coupling of myotubes (15,35). Importantly, Homer-1a alone had no effect on RyR1 activity, but it dose-dependently decreased the effects of Homer-1c on RyR1 (36). In conclusion, Homer proteins modulate the function of the target protein RyR1 in skeletal muscle.

\section{Ryanodine Receptor Type 2 (RyR2)}

Another type of calcium-activated calcium channel, RyR2, physically interacts with Homer-1c (37). In contrast to RyR1, Homer-1c decreased the function of RyR2 as it reduced both the cyclic ADP ribose- and the caffeineinduced $\mathrm{Ca}^{2+}$ release mediated by RyR2 from cardiac sarcoplasmic reticulum microsomes (37). The reduction in RyR2 activity results from a decrease in the open probability of the RyR2 channel. Although Homer-1a alone had no significant effect on RyR2 function, it reversed the Homer-1c effects. These findings, together with the data on RyR1 described above, demonstrate that varying RyR isoforms are differentially regulated by Homer proteins to control muscle function.

\section{C-Type Transient Receptor Potential (TRPC) Channels}

A recent paper reports that Homer proteins bind TRPC channels via their EVH1 domain (38). TRPC channels are nonspecific cation channels activated by $G$ protein-coupled receptors and/or depletion of intracellular calcium stores, e.g., via $\mathrm{IP}_{3}$ receptors (39). Through two distinct binding sites in the TRPC N- and C-termini Homer-1 and 3 proteins bind TRPC1 and 5, but Homer-1 pro- teins also bind TRPC2, whereas Homer-3 proteins additionally bind TRPC 4 (38). The interaction with Homer proteins is critical for regulating TRPC channel activity because the agonist-stimulated activity of overexpressed TRPC1 in HEK 293 cells (detected with electrophysiological and intracellular $\mathrm{Ca}^{2+}$ imaging techniques) was mimicked in the absence of agonists by both (a) a TRPC1 mutant with impaired Homer binding site, and (b) cotransfection of wild-type TRPC1 with Homer-1a, which is unable to multimerize (38). These results indicate that long forms of Homer proteins physically associate TRPC1 channels with $\mathrm{IP}_{3}$ receptors into a signal-responsive TRPC channel complex, while the IEG Homer-1a blocks this interaction. Interestingly, the interaction between Homer-3 and TRPC1 was dissociated by thapsigargin, which depletes intracellular $\mathrm{Ca}^{2+}$ stores (38). The following model for cellular calcium homeostasis was proposed: Depletion of intracellular calcium stores activates TRPC channels by relieving their block by long Homer forms, thus causing extracellular $\mathrm{Ca}^{2+}$ influx. When intracellular $\mathrm{Ca}^{2+}$ stores are refilled, long Homer proteins associate with TRPC proteins again to diminish TRPC channel activity back to resting state.

\section{Dynamin 3}

Dynamin proteins, formed by a family of three different genes, constitute mechanoenzymes with GTPase activity that are involved in vesicle trafficking (40). After the original proposal of an interaction between dynamin 3 and Homer proteins (22), it was recently shown that dynamin 3 is present in dendritic spines of hippocampal neurons where it forms, in contrast to dynamin 1, a complex with Homer proteins and mGluR5 (41). However, coexpression of an epitope-tagged mGluR5 with a putative dominant-negative form of dynamin 3 (containing a mutation in the GTPase domain) did not affect mGluR5 internalization, indicating that dynamin 3 is not involved in mGluR5 trafficking (41). 


\section{Cdc42}

The C-terminal portion of Homer-2a has been shown to interact with the GTP-bound, active form of Cdc42, a member of the Rho family of monomeric G proteins (1). HeLa cells expressing a constitutively active Cdc42 variant lead to filopodia-like structures, while coexpression of Homer-2a with Cdc42 diminished these structures (1). Although it cannot be ruled out that sequestering of active Cdc42 by Homer-2a suppressed filopodia formation, the data may suggest that Homer-2a affects cytoskeletal dynamics via the recruitment of active Cdc42.

\section{Syntaxin 13}

By using a yeast two-hybrid screening with the C-terminal region of Homer-1c as bait, syntaxin 13 has been identified as a Homer-1c binding partner (42). Both Homer-1c and syntaxin 13 possess at their C-terminus CC domains via which the interaction is proposed. syntaxin 13 binding is selective for Homer-1c, as it does not occur with Homer-2. Because Syntaxin 13 is a typical component of recycling endosomes, Homer-1c might affect the trafficking of, e.g., mGluRs that are linked to Homer proteins (see Fig. 2).

\section{Functional Effects of Homer Proteins}

\section{Coupling of mGluRs to Calcium and Potassium Channels}

In superior cervical ganglion neurons, group I mGluRs can regulate N-type calcium currents in three ways: (a) a voltage-dependent mechanism, (b) a voltage-independent pathway (43), and (c) a $\mathrm{G}_{\beta \gamma}$-mediated pathway (44). In this preparation, it was demonstrated that overexpression of the long Homer forms rather than Homer-1a reduces mGluR-mediated inhibition of N-type calcium currents (43). In addition, coexpression of Homer-1a counteracted the reduction of calcium current modulation by Homer-
$1 b / 1 c / 2 / 3$, suggesting a dominant-negative role for the IEG Homer form. The specificity of this regulatory role for type I mGluRs was demonstrated by the fact that neither Homer3 nor Homer-1a affected the voltage-dependent inhibition of N-type calcium currents by mGluR2.

The same study also showed that long Homer forms (Homer-1b/c/2/3) reduce mGluR1a signaling to M-type potassium channels without altering the voltage-dependence of glutamateinduced calcium current inhibition (43). As it is known that activating group I mGluRs inhibits M-type potassium currents via a G-proteindependent mechanism (45), it appears that the long Homer forms inhibit signal transduction from mGluR1a/5 to G-proteins, thus regulating both N-type calcium and M-type potassium channels. Homer- $1 \mathrm{a}$, in contrast, acts as a dominant-negative competitor interfering with the action of the long Homer forms.

The effect of Homer protein binding on the activity of type I mGluRs was shown in cultured cerebellar granule cells by measuring the activity of $\mathrm{Ca}^{2+}$-activated $\mathrm{BK}$ channels (46). In this test system, both overexpression of exogenous Homer-1a and induction of endogenous Homer-1a increased BK channel activity even in the presence of competitive mGluR1a/5 antagonists. Similar data were obtained by suppressing endogenous Homer-3 with antisense oligonucleotides and by disrupting the mGluR-Homer interaction. Based on these results, it was concluded that the long forms of Homer proteins suppress agonist-independent activity of mGluRs, while the IEG form Homer-1a increases this activity (46).

\section{Regulation of Axonal Pathfinding}

Homer proteins may also play a role in axon guidance as Xenopus optic tectal neurons overexpressing normal Homer-1a formed aberrant axon projections (47). In contrast to wild-type Homer-1a, overexpression of a Homer-1a point mutant (Homer-1aW24A) that does not bind Homer ligands caused no such abnormal axonal projections. Interestingly, similar to 

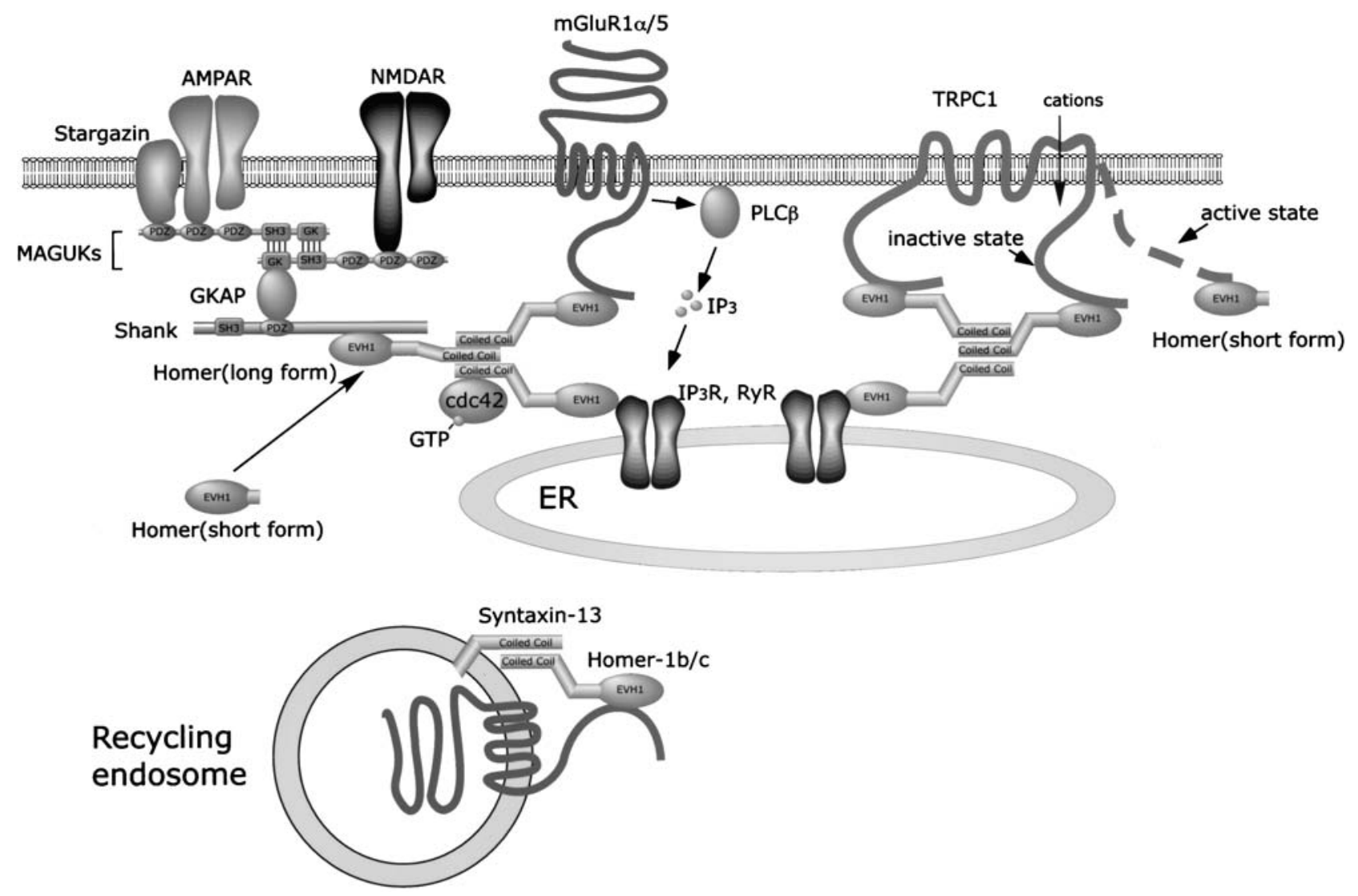

Fig. 2. Schematic representation of the postsynaptic protein interactions that involve Homer proteins. The EVH1 domain of Homer proteins binds mGluR1a/5 (which in turn couple to phospholipase C; PLC), intracellular calcium channels (IP ${ }_{3} R$, RyRs), and PSD proteins (Shank/ProSAP) that interact with ionotropic glutamate receptors. CC domains in the C- terminal region of the long Homer forms (Homer- $1 \mathrm{~b} / \mathrm{c}$, Homer-2a/b, and Homer-3) permit homo- and heteromultimerization. In contrast to the long Homer forms, the inducible Homer proteins Homer-1a and Ania-3 lack CC domains. These short Homer isoforms supposedly disrupt protein complexes that are mediated by constitutively expressed long Homer proteins. MAGUKs are membrane-associated PDZ proteins that contain guanylate kinase-like domains (PSD95, PSD93, SAP97, and SAP102). Long forms of Homer proteins bind TRPC1 channels and suppress their activity. When Homer-1a is upregulated, it replaces the constitutively expressed Homer proteins from TRPC1 channels and thus removes the block of constitutive activity. The C-terminal region of Homer-2 has been reported to associate with active Cdc42, while Homer-1c has been described to bind to Syntaxin 13 from recycling endosomes.

wild-type Homer-1a, overexpression of Homer-1c and Homer-1cW24A (which has the same point mutation as Homer-1aW24A but can dimerize with endogenous Homer-1b/c) also leads to axonal pathfinding errors. Homer-1a/c expression levels within the axonal growth cone thus appear to be critical for effective signal transduction related to the correct targeting of axons.

\section{Lateral Movement of mGluR5}

One study examined the lateral movement of exogenously expressed, epitope-tagged mGluR5 
in both primary hippocampal neurons and Ptk2 cells (48). The movement of mGluR5 was divided into two phases: (a) a diffusing phase in which mGluR5 moves quite freely, and (b) a confined phase in which mGluR5 is more trapped. While mGluR5 mobility increased with receptor activation, it decreased by coexpressing Homer$1 b$. In addition, the surface distribution of exogenous mGluR5 was uniform in both primary neurons and Ptk2 cells transfected with mGluR5 alone, whereas it was patchy in cells cotransfected with mGluR5 and Homer-1b. These results are compatible with the previously described effects of Homer proteins on the cell surface clustering of mGluRla/5 (see above) and show that mGluR5 binding into larger protein complexes results in slower lateral receptor diffusion.

\section{Animal Behavior}

To establish the function of Homer proteins in Drosophila locomotor activity and behavioral plasticity, mutant flies were generated (homer ${ }^{\mathrm{R} 102}$ ) in which the first two exons and half of the third exon of the homer gene were removed (7). A role for Homer in behavioral plasticity was verified by evaluating the performance of homer ${ }^{\mathrm{R} 102}$-mutant males in a courtshipconditioning assay, an associative learning paradigm in Drosophila (49). Male flies react to olfactory, visual, and tactile signals with a complex and strong courtship toward females, and this behavior can be conditioned by previous experience. As compared with wild-type flies, homerR102 mutants were lacking behavioral plasticity and failed to form and/or retain the conditioning by the nonreceptive mated female (7). In addition, homer ${ }^{\mathrm{R} 102}$-mutant flies exhibited higher levels of spontaneous locomotor activity. It thus appears that Homer, at least in Drosophila, is important in the development and function of neuronal networks underlying locomotion and behavioral plasticity.

Homer proteins have also been implicated in cocaine-induced behavioral plasticity in rats (50). Activation of mGluRs by dialyzing the group I mGluR agonist DHPG into the medial nucleus accumbens augments both the extracellular glutamate concentration and locomotor activity. In this system, repeated cocaine administration increased group I mGluRinduced glutamate release and locomotor activity in parallel with a reduction in Homer$1 \mathrm{~b} / \mathrm{c}$ protein.

\section{Spine Maturation and Synaptic Function}

Many of the regulatory proteins involved in the dynamic morphological rearrangement of spines are embedded within the PSD. Using quantitative morphometric analysis of spines in cultured hippocampal neurons, Shank overexpression was shown to promote the development and enlargement of spine heads (3). These changes did not occur when a Shank mutant was used that does not bind Homer-1b protein any more. Moreover, overexpression of this Shank mutant decreased the amount of endogenous Homer- $1 \mathrm{~b}$ in spines, and reduced the number of dendritic spines (3). While Homer- $1 \mathrm{~b}$ overexpression in the absence of Shank had no detectable effect on spine morphology, coexpression of both Shank and Homer- $1 \mathrm{~b}$ caused a more pronounced spine growth and increased the frequency of miniature excitatory postsynaptic currents (3). These data suggest that an unknown retrograde signal triggers the maturation of presynaptic function.

To study the synaptic function of Homer-1a and Homer-1c in hippocampal neurons, we used Semliki Forest virus vectors $(51,52)$ to upregulate these proteins. We found that overexpression of Homer-1a enhanced AMPA receptor function and clustering, whereas it affected neither NMDA receptor function and clustering nor presynaptic glutamate release (53). In contrast to Homer-1a, Homer-1c overexpression did not alter synaptic transmission. While Homer-1a resulted in a greater AMPA-to-NMDA ratio in mEPSCs (recorded in the presence of tetrodotoxin), the NMDA component remained constant. In addition, the increase in AMPA-to-NMDA ratio caused by Homer-1a was higher for evoked EPSCs than for mEPSCs. We therefore proposed in 


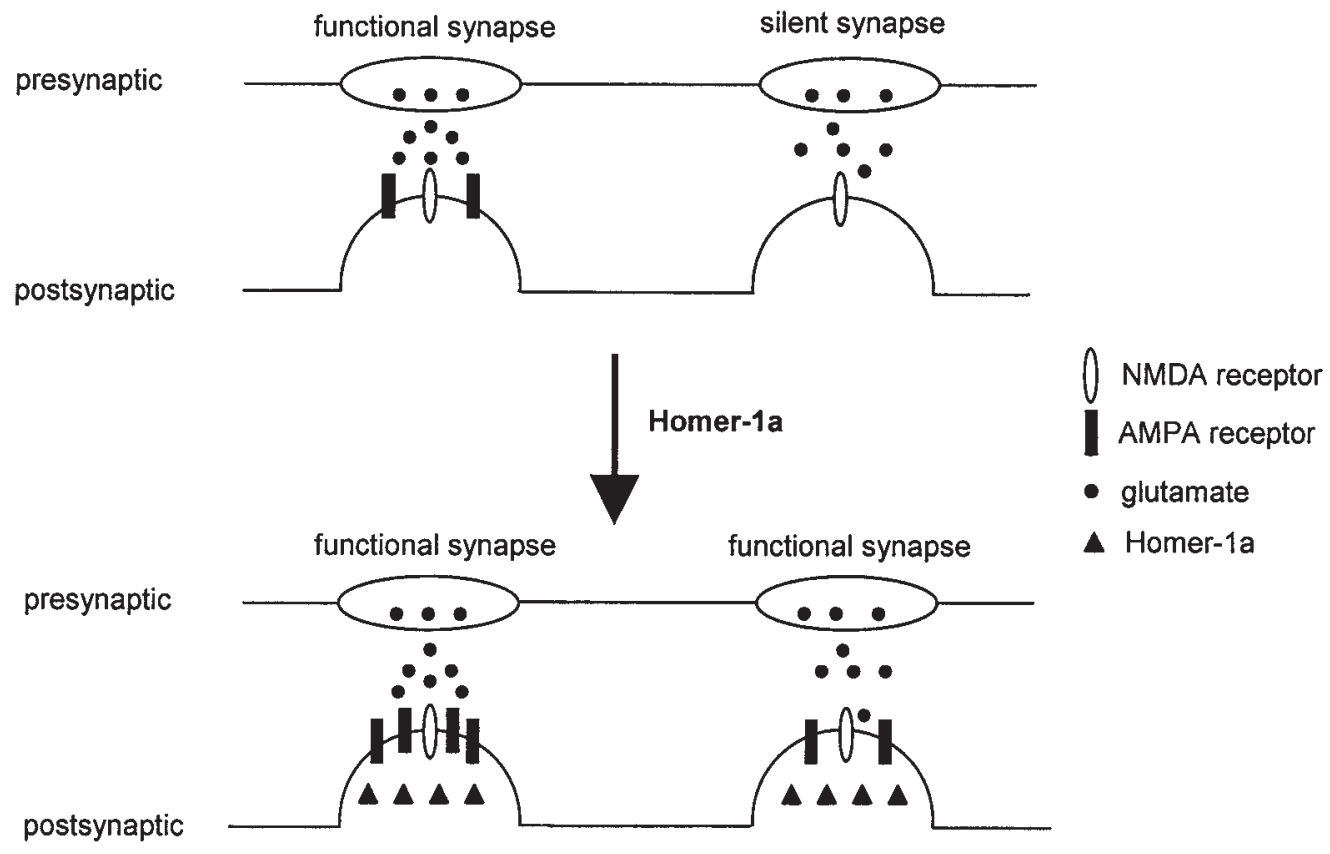

Fig. 3. Working model for the effect of Homer-1a on hippocampal synaptic transmission. Presynaptic release of glutamate into the synaptic cleft can activate two kinds of synapses: (a) functional synapses, i.e., synapses containing both NMDA and AMPA receptors (open and closed symbols, respectively), and (b) "silent synapses" that contain NMDA receptors but lack functional AMPA receptors. Overexpression of Homer-1a (triangles) induces an increase in the synaptic transmission without changing the glutamate release (circles). Our experiments lead to the conclusion that more AMPA receptors are expressed in functional synapses, but also in nonfunctional ones, which represents a conversion of silent synapses into functional ones.

our previous study (53) that Homer-1a promotes AMPA receptor insertion at both functional synapses (containing AMPA and NMDA receptors) and previously silent synapses (expressing only NMDA receptors; Fig. 3).

In contrast to our data, Sala et al. recently reported Homer-1a to inhibit rather than enhance hippocampal synaptic transmission (54). In their study, Homer-1a overexpression caused shrinkage of dendritic spines and a decrease in both AMPA and NMDA receptor currents. The apparent contradiction between these and our data may result from different experimental protocols used. While we examined hippocampal slices prepared from postnatal day 6 (P6) rats and cultured for 2-3 wk (in the roller-tube configuration), Sala et al employed slices from P8 rats at 4-6 d in culture (stationary on membranes). For dissociated hippocampal neurons, we used 3-4-wk-old cultures and Sala et al. 12-d-old cultures. Our experiments were thus conducted with more mature cultures, which might explain the discrepancy of the data. In addition, we employed conventional Semliki Forest virus vectors for gene transfer and analyzed the neurons at 1-2 d after transduction, whereas Sala et al. applied $\mathrm{Ca}^{2+}$ phosphate precipitation for dissociated neurons and a biolistic gene gun for slices and examined them at 4-5 and $2 \mathrm{~d}$ posttransfection, respectively (note that under physiological conditions Homer-1a protein is induced within few 
hours of neuronal activation). Differences in transgene expression levels thus obtained with varying transfection techniques could also affect the experimental outcome. In any case, a positive feed-forward role, rather than a negative feedback function of Homer-1a in hippocampal synaptic transmission, seems to be a more straightforward explanation for Homer-1a being induced with protocols causing hippocampal long-term potentiation. In addition, our results agree with a recent report showing in the nucleus accumbens that downregulation of Homer-1b/c with antisense oligonucleotides specifically decreases the protein level of the AMPA receptor subunit GluR1 (55).

\section{Conclusion}

A rapidly increasing number of investigations provide data that support a role for Homer proteins in synaptic plasticity. The functions of Homer proteins result from their particular structural properties that permit them to interact with membrane receptors, such as mGluRs, but also with intracellular receptors, including Shank, $\mathrm{IP}_{3} \mathrm{Rs}$, and RyRs. It thus appears that Homer proteins not only are important in receptor scaffolding, but also modulate receptor activity. Intracellular $\mathrm{Ca}^{2+}$ is implicated in several mechanisms that lead to the potentiation of synapses, and Homer proteins have been shown to control intracellular $\mathrm{Ca}^{2+}$ homeostasis by regulating type I mGluRs, $\mathrm{IP}_{3} \mathrm{Rs}$, RyRs, TRPC channels, and voltagegated $\mathrm{Ca}^{2+}$ channel activity. It is therefore probable that Homer proteins are also involved in hippocampal synaptic plasticity.

\section{Acknowledgments}

Our work was supported by grant no. 31-57125.99 from the Swiss National Science Foundation. We are grateful to Dr. Beat H. Gähwiler for helpful discussions and to Dr. Urs Gerber for comments on the manuscript.

\section{References}

1 Shiraishi Y., Mizutani A., Bito H., Fujisawa K., Narumiya S., Mikoshiba K., et al. (1999) Cupidin, an isoform of Homer/Vesl, interacts with the actin cytoskeleton and activated Rho family small GTPases and is expressed in developing mouse cerebellar granule cells. J. Neurosci. 19, 8389-8400.

2 Kato A., Fukuda T., Fukazawa Y., Isojima Y., Fujitani K., et al. (2001) Phorbol esters promote postsynaptic accumulation of Vesl-1S/Homer1a protein. Eur. J. Neurosci. 13, 1292-1302.

3 Sala C., Piëch V., Wilson N.R., Passafaro M., Liu G., and Sheng M. (2001) Regulation of dendritic spine morphology and synaptic function by Shank and Homer. Neuron 31, 115-130.

4. Usui S., Konno D., Hori K., Maruoka H., Okabe S., Fujikado T., et al. (2003) Synaptic targeting of PSD-Zip45 (Homer 1c) and its involvement in the synaptic accumulation of F-actin. J. Biol. Chem. 278, 10,619-10,628.

5. Kato A., Ozawa F., Saitoh Y., Fukazawa Y., Sugiyama H., and Inokuchi K. (1998) Novel members of the Vesl/Homer family of PDZ proteins that bind metabotropic glutamate receptors. J. Biol. Chem. 273, 23,969-23,975.

6 Xiao B., Tu J.C., Petralia R.S., Yuan J.P., Doan A., Breder C.D., et al. (1998) Homer regulates the association of group 1 metabotropic glutamate receptors with multivalent complexes of Homerrelated, synaptic proteins. Neuron 21, 707-716.

7 Diagana T.T., Thomas U., Prokopenko S.N., Xiao B., Worley P.F., and Thomas J.B. (2002) Mutation of Drosophila homer disrupts control of locomotor activity and behavioral plasticity. J. Neurosci. 22, 428-436.

8 Brakeman P.R., Lanahan A.A., O'Brien R., Roche K., Barnes C.A., Huganir R.L., et al. (1997) Homer: a protein that selectively binds metabotropic glutamate receptors. Nature 386, 284-288.

9 Kato A., Ozawa F., Saitoh Y., Hirai K., and Inokuchi K. (1997) vesl, a gene encoding VASP/ Ena family related protein, is upregulated during seizure, long-term potentiation and synaptogenesis. FEBS Lett. 412, 183-189.

10 Berke J.D., Paletzki R.F., Aronson G.J., Hyman S.E., and Gerfen C.R. (1998) A complex program of striatal gene expression induced by dopaminergic stimulation. J. Neurosci. 18, 5301-5310.

11 Bottai D., Guzowski J.F., Schwarz M.K., Kang S.H., Xiao B., Lanahan A., et al. (2002) Synaptic 
activity-induced conversion of intronic to exonic sequence in Homer 1 immediate early gene expression. J. Neurosci. 22, 167-175.

12 Sun J., Tadokoro S., Imanaka T., Murakami S.D., Nakamura M., Kashiwada K., et al. (1998) Isolation of PSD-Zip45, a novel Homer/vesl family protein containing leucine zipper motifs, from rat brain. FEBS Lett. 437, 304-308.

13 Soloviev M.M., Ciruela F., Chan W.-Y., and Mcllhinney R.A.J. (2000) Mouse brain and muscle tissues constitutively express high levels of Homer proteins. Eur. J. Biochem. 267, 634-639.

14 Kaja S., Yang S.-H., Wei J., Fujitani K., Liu R., Brun-Zinkernagel A.-M., et al. (2003) Estrogen protects the inner retina from apoptosis and ischemia-induced loss of Vesl-1L/Homer 1c immunoreactive synaptic connections. Invest. Ophthalmol. Vis. Sci. 44, 3155-3162.

15. Sandonà D., Tibaldo E., and Volpe P. (2000) Evidence for the presence of two Homer 1 transcripts in skeletal and cardiac muscles. Biochem. Biophys. Res. Commun. 279, 348-353.

16 Fanning A.S. and Anderson J.M. (1998) PDZ domains and the formation of protein networks at the plasma membrane. Curr. Top. Microbiol. Immunol. 228, 209-233.

17 Hata Y., Nakanishi H., and Takai Y. (1998) Synaptic PDZ domain-containing proteins. Neurosci. Res. 32, 1-7.

18 Gertler F.B., Niebuhr K., Reinhard M., Wehland J., and Soriano P. (1996) Mena, a relative of VASP and Drosophila Enabled, is implicated in the control of microfilament dynamics. Cell 87, 227-239.

19 Haffner C., Jarchau T., Reinhard M., Hoppe J., Lohmann S.M., and Walter U. (1995) Molecular cloning, structural analysis and functional expression of the proline-rich focal adhesion and microfilament-associated protein VASP. EMBO J. 14, 19-27.

20 Reinhard M., Halbrugge M., Scheer U., Wiegand C., Jockusch B.M., and Walter U. (1992) The 46/50 kDa phosphoprotein VASP purified from human platelets is a novel protein associated with actin filaments and focal contacts. EMBO J. 11, 2063-2070.

21 Callebaut I., Cossart P., and Dehoux P. (1998) EVH1/WH1 domains of VASP and WASP proteins belong to a large family including Ranbinding domains of the RanBP1 family. FEBS Lett. 441, 181-185.

22 Tu J.C., Xiao B., Yuan J.P., Lanahan A.A., Leoffert K., Li M., et al. (1998) Homer binds a novel proline-rich motif and links group 1 metabotropic glutamate receptors with IP3 receptors. Neuron 21, 717-726.

23 Beneken J., Tu J.C., Xiao B., Nuriya M., Yuan J.P., Worley P.F., et al. (2000) Structure of the Homer EVH1 domain-peptide complex reveals a new twist in polyproline recognition. Neuron 26, 143-154.

24 Tadokoro S., Tachibana T., Imanaka T., Nishida W., and Sobue K. (1999) Involvement of unique leucine-zipper motif of PSD-Zip45 (Homer 1c/vesl-1L) in group 1 metabotropic glutamate receptor clustering. Proc. Natl. Acad. Sci. USA 96, 13,801-13,806.

25 Roche K.W., Tu J.C., Petralia R.S., Xiao B., Wenthold R.J., and Worley P.F. (1999) Homer $1 \mathrm{~b}$ regulates the trafficking of group I metabotropic glutamate receptors. J. Biol. Chem. 274, 25,953-25,957.

26 Coutinho V., Kavanagh I., Sugiyama H., Tones M.A., and Henley J.M. (2001) Characterization of a metabotropic glutamate receptor type 5green fluorescent protein chimera (mGluR5GFP): pharmacology, surface expression, and differential effects of Homer-1a and Homer-1c. Mol. Cell Neurosci. 18, 296-306.

27 Ciruela F., Soloviev M.M., and McIlhinney R.A.J. (1999) Co-expression of metabotropic glutamate receptor type $1 \alpha$ with Homer1a/Vesl-1S increases the cell surface expression of the receptor. Biochem. J. 341, 795-803.

28 Ciruela F., Soloviev M.M., Chan W.-Y., and McIlhinney R.A.J. (2000) Homer-1c/Vesl-1L modulates the cell surface targeting of metabotropic glutamate receptor type $1 \alpha$ : evidence for an anchoring function. Mol. Cell. Neurosci. 15, 36-50.

29 Ango F., Pin J.-P., Tu J.C., Xiao B., Worley P.F., Bockaert J., et al. (2000) Dendritic and axonal targeting of type 5 metabotropic glutamate receptor is regulated by Homer1 proteins and neuronal excitation. J. Neurosci. 20, 8710-8716.

30 Berridge M.J. (1998) Neuronal calcium signaling. Neuron 21, 13-26.

31 Satoh T., Ross C.A., Villa A., Supattapone S., Pozzan T., Snyder S.H., et al. (1990) The inositol 1,4,5,-trisphosphate receptor in cerebellar Purkinje cells: quantitative immunogold labeling reveals concentration in an ER subcompartment. J. Cell Biol. 111, 615-624.

32 MacKrill J.J. (1999) Protein-protein interactions in intracellular $\mathrm{Ca}^{2+}$-release channel function. Biochem. J. 337 (Pt 3), 345-361. 
33 Ango F., Robbe D., Tu J.C., Xiao B., Worley P.F., Pin J.P., et al. (2002) Homer-dependent cell surface expression of metabotropic glutamate receptor type 5 in neurons. Mol. Cell. Neurosci. 20, 323-329.

34 Tu J.C., Xiao B., Naisbitt S., Yuan J.P., Petralia R.S., Brakeman P., et al. (1999) Coupling of mGluR/Homer and PSD-95 complexes by the Shank family of postsynaptic density proteins. Neuron 23, 583-592.

35. Feng W., Tu J., Yang T., Vernon P.S., Allen P.D., Worley P.F., et al. (2002) Homer regulates gain of ryanodine receptor type 1 channel complex. J. Biol. Chem. 277, 44,722-44,730.

36 Hwang S.-Y., Wei J., Westhoff J.H., Duncan R.S., Ozawa F., Volpe P., et al. (2003) Differential functional interaction of two Vesl/Homer protein isoforms with ryanodine receptor type 1: a novel mechanism for control of intracellular calcium signaling. Cell Calcium 34, 177-184.

37 Westhoff J.H., Hwang S.-Y., Duncan R.S., Ozawa F., Volpe P., Inokuchi K., et al. (2003) Vesl/Homer proteins regulate ryanodine receptor type 2 function and intracellular calcium signaling. Cell Calcium 34, 261-269.

38 Yuan J.P., Kiselyov K., Shin D.M., Chen J., Shcheynikov N., Kang S.H., et al. (2003) Homer binds TRPC family channels and is required for gating of TRPC1 by $\mathrm{IP}_{3}$ receptors. Cell 114, 777-789.

39 Montell C., Birnbaumer L., and Flockerzi V. (2003) The TRP channels, a remarkably functional family. Cell 108, 595-598.

40 McNiven M.A., Cao H., Pitts K.R., and Yoon Y. (2000) The dynamin family. Trends Biochem. Sci. $25,115-120$.

41 Gray N.W., Fourgeaud L., Huang B., Chen J., Cao H., Oswald B., et al. (2003) Dynamin 3 is a component of the postsynapse, where it interacts with mGluR5 and Homer. Curr. Biol. 13, 510-515.

42 Minakami R., Kato A., and Sugiyama H. (2000) Interaction of Vesl-1L/Homer 1c with synatxin 13. Biochem. Biophys. Res. Commun. 272, 466-471.

43 Kammermeier P.J., Xiao B., Tu J.C., Worley P.F., and Ikeda S.R. (2000) Homer proteins regulate coupling of group I metabotropic glutamate receptors to N-type calcium and M-type potassium channels. J. Neurosci. 20, 7238-7245.

44 Herlitze S., Garcia D.E., Mackie K., Hille B., Scheuer T., and Catterall W.A. (1996) Modulation of $\mathrm{Ca}^{2+}$ channels by G-protein beta gamma subunits. Nature 380, 258-262.
45 Charpak S., Gähwiler B.H., Do K.Q., and Knöpfel T. (1990) Potassium conductances in hippocampal neurons blocked by excitatory amino-acid neurotransmitters. Nature 347, 765-767.

46 Ango F., Prézeau L., Muller T., Tu J.C., Xiao B., Worley P.F., et al. (2001) Agonist-independent activation of metabotropic glutamate receptors by the intracellular protein Homer. Nature 411, 962-965.

47 Foa L., Rajan I., Haas K., Wu G.-Y., Brakeman P., Worley P., et al. (2001) The scaffold protein, Homer1b/c, regulates axon pathfinding in the central nervous system in vivo. Nat. Neurosci. 4, 499-506.

48. Sergé A., Fourgeaud L., Hémar A., and Choquet D. (2003) Receptor activation and Homer differentially control the lateral mobility of metabotropic glutamate receptor 5 in the neuronal membrane. J. Neurosci. 22, 3910-3920.

49 Kamyshev N.G., Iliadi K.G., and Bragina J.V. (1999) Drosophila conditioned courtship: two ways of testing memory. Learn. Mem. 6, 1-20.

50 Swanson C.J., Baker D.A., Carson D., Worley P.F., and Kalivas P.W. (2001) Repeated cocaine administration attenuates group I metabotropic glutamate receptor-mediated glutamate release and behavioral activation: a potential role for Homer. J. Neurosci. 21, 9043-9052.

51 Ehrengruber M.U. (2002) Alphaviral vectors for gene transfer into neurons. Mol. Neurobiol. 26, 183-201.

52 Ehrengruber M.U. (2002) Alphaviral gene transfer in neurobiology. Brain Res. Bull. 59, 13-22.

53 Hennou S., Kato A., Schneider E.M., Lundstrom K., Gähwiler B.H., Inokuchi K., et al. (2003) Homer-1a/Vesl-1S enhances hippocampal synaptic transmission. Eur. J. Neurosci. 18, 811-819.

54 Sala C., Futai K., Yamamoto K., Worley P.F., Hayashi Y., and Sheng M. (2003) Inhibition of dendritic spine morphogenesis and synaptic transmission by activity-inducible protein Homer1a. J. Neurosci. 23, 6327-6337.

55 Ghasemzadeh M.B., Permenter L.K., Lake R., Worley P.F., and Kalivas P.W. (2003) Homer1 proteins and AMPA receptors modulate cocaine-induced behavioural plasticity. Eur. J. Neurosci. 18, 1645-1651.

56 Morioka R., Kato A., Fueta Y., and Sugiyama H. (2001) Expression of vesl-1S/homer-1a, a gene associated with long-term potentiation, in the brain of the epileptic EI mouse. Neurosci. Lett. 313, 99-101. 
57 Park H.T., Kang E.K., and Bae K.W. (1997) Light regulates Homer mRNA expression in the rat suprachiasmatic nucleus. Mol. Brain Res. 52, 318-322.

58 Nielsen H.S., Georg B., Hannibal J., and Fahrenkrug J. (2002) Homer-1 mRNA in the rat suprachiasmatic nucleus is regulated differentially by the retinohypothalamic tract transmitters pituitary adenylate cyclase activating polypeptide and glutamate at time points where light phase-shifts the endogenous rhythm. Brain Res. Mol. Brain Res. 105, 79-85.

59. Vazdarjanova A., McNaughton B.L., Barnes C.A., Worley P.F., and Guzowski J.F. (2002) Experience-dependent coincident expression of the effector immediate-early genes arc and Homer 1a in hippocampal and neocortical neuronal networks. J. Neurosci. 22, 10,067-10,071.

60 Polese D., de Serpis A.A., Ambesi-Impiombato A., Muscettola G., and de Bartolomeis A. (2002) Homer 1a gene expression modulation by antipsychotic drugs: involvement of the glutamate metabotropic system and effects of Dcycloserine. Neuropsychopharmacology 27, 906-913.
61 de Bartolomeis A., Aloj L., Ambesi-Impiombato A., Bravi D., Caracò C., Muscettola G., et al. (2002) Acute administration of antipsychotics modulates Homer striatal gene expression differentially. Brain Res. Mol. Brain Res. 98, 124-129.

62 Ageta H., Kato A., Hatakeyama S., Nakayama K., Isojima Y., and Sugiyama H. (2001) Regulation of the level of Vesl-1S/Homer-1a proteins by ubiquitin-proteasome proteolytic systems. J. Biol. Chem. 276, 15,893-15,897.

63. Ageta H., Kato A., Fukazawa Y., Inokuchi K., and Sugiyama H. (2001) Effects of proteasome inhibitors on the synaptic localization of Vesl1S/Homer-1a proteins. Mol. Brain Res. 97, 187-189.

64 Sato M., Suzuki K., and Nakanishi S. (2001) NMDA receptor stimulation and brain-derived neurotrophic factor upregulate homer 1a mRNA via the mitogen-activated protein kinase cascade in cultured cerebellar granule cells. J. Neurosci. 21, 3797-3805.

65. Thomas U. (2002) Modulation of synaptic signalling complexes by Homer proteins. J. Neurochem. 81, 407-413. 